\title{
VYUŽITÍ MATEMATICKÝCH METOD V EKONOMII NA PŘÍKLADU PROBLÉMŮ NEJMÉNĚ ROZVINUTÝCH ZEMÍ
}

\author{
Ingrid Majerová ${ }^{1}$
}

\section{Klíčová slova:}

teorie her, nejméně rozvinuté země (LDC), mezinárodní obchod, monopol, herní strom, matice

\section{Key words:}

game theory, Least Developed Countries (LDCs), international trade, monopoly, game three, matrix

\begin{abstract}
Abstrakt
Příspěvek je zaměřen na využití matematických metod v ekonomii, konkrétně na aplikaci teorie her v mezinárodních vztazích. Jsou zde analyzovány možnosti použití výše uvedených skupin her v obchodní politice či mezinárodní ekonomii, a to s důrazem na skupinu nejméně vyspělých ekonomik (LDC), které nejsou schopny dosáhnout zisků z mezinárodního obchodu na základě neadekvátních znalostí v oblasti problematiky trhu. Pro tuto analýzu bude použita metoda stromu a maticový výpočet.
\end{abstract}

\begin{abstract}
The paper aims at the use of mathematical methods in economics, namely the game theory application in international relations. The possibility of applying the above-mentioned groups of games in trade policy and international economics is analyzed, emphasizing the group of the Least Developed Countries that are unable to reap the benefits of international trade due to inadequate knowledge of trade issues. The method of game tree and matrix were used in this analysis.
\end{abstract}

\section{Úvod}

Teorie her je matematická disciplína, která studuje strategie výběru interakcí racionálních účastníků. Základem analýzy teorie her je určit, která strategie je nejlepší odpovědí na strategii zvolenou ostatními účastníky. Teorie her je vědecká metafora, není to jen nalezení strategie v určitých hrách, ale i v jiných oblastech lidské činnosti, zejména $\mathrm{v}$ ekonomice, obraně a dopravě, zemědělství apod. Existuje mnoho variant teorie her: hra se dvěma nebo více účastníky, s nulovým nebo nenulovým součtem, s dokonalými a nedokonalými informacemi, s dominantní strategií či Nashova rovnováha. V některých hrách jeden účastník vždy vyhraje a druhý prohraje, $v$ jiných mohou oba vyhrát. Tento článek se zaměřuje na aplikaci teorie her v mezinárodních vztazích, kdy je analyzována možnost uplatnění výše uvedených skupin her v obchodní politice a mezinárodní ekonomii, s důrazem na skupinu nejméně rozvinutých zemí, které nejsou schopny plně využít výhod mezinárodního obchodu kvưli nedostatečným znalostem obchodní problematiky.

\footnotetext{
${ }^{1}$ Tento př́íspěvek vznikl za podpory Slezské univerzity v Opavě v rámci projektu Interního grantového systému IGS 3/2011: „Ekonomické a politické aspekty vývoje zemí LDC a jejich perspektivy v rámci světové ekonomiky“.
} 
Teorie her, jako jedna z matematických metod, je nejen nedílnou součástí ekonomiky, ale i dalších disciplín, jako je obrana, biologie, medicína, životní prostředí, právo, telekomunikace a doprava, média, zemědělství a podobně (viz obrázek 1) nebo každodenního života. Každá z těchto disciplín je vystavena situacím, u kterých musí zvolit vhodnou strategii, aby dosáhla co nejlepších výsledků. Je-li toto rozhodnutí ovlivněno rozhodnutími jiných účastníků, můžeme hovořit o principu teorie her. Jak je popsáno dále, neexistuje jednotná definice toho, co je to teorie her. V článku budou popsány pouze ty nejvýstižnější a nejčastěji používané v praxi. V kontrastu s neexistencí definice je pak přesné rozdělení skupin teorie her, které budou také analyzovány (hra o dvou nebo více účastnících, s nulovým nebo nenulovým součtem, s dokonalými nebo nedokonalými informacemi, s dominantní rovnovážnou strategií nebo Nashovou rovnováhou).

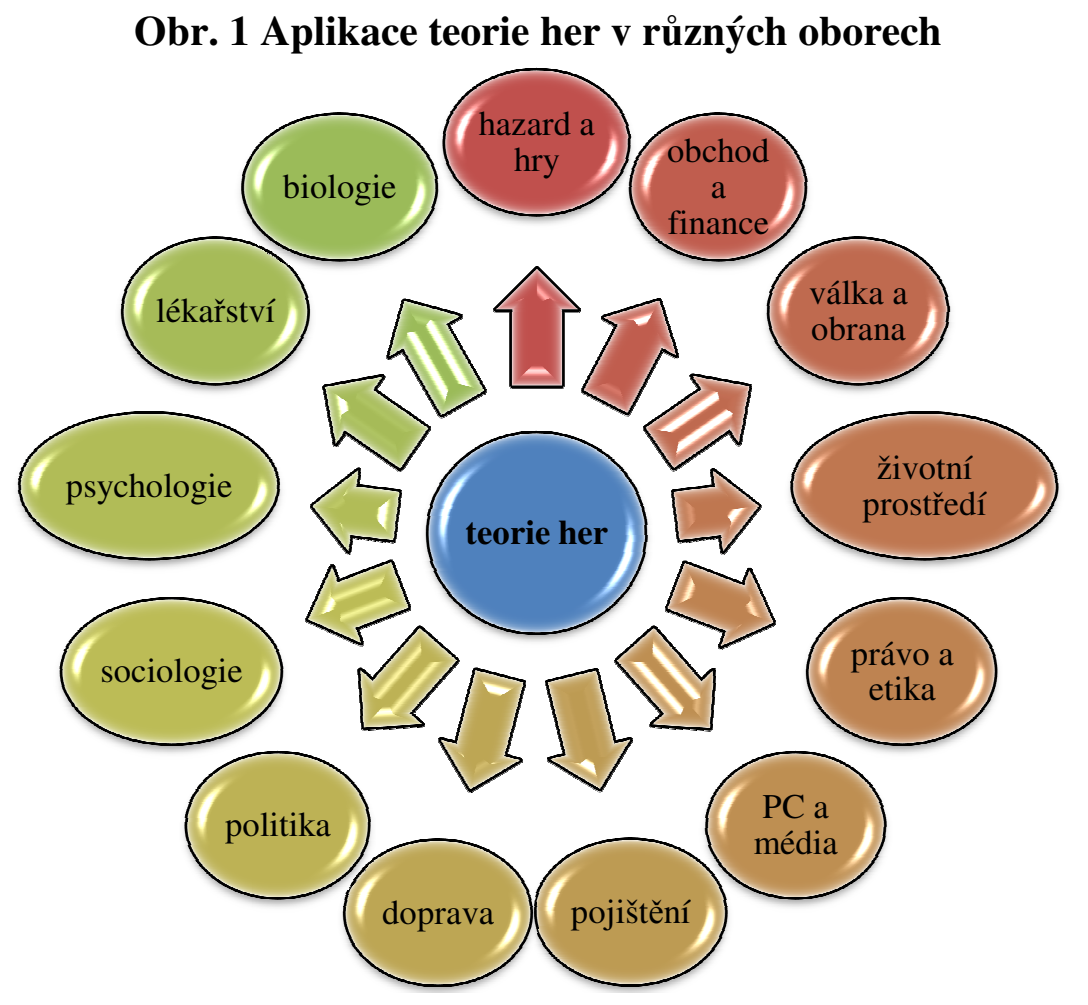

Pramen: vlastní zpracování

Ačkoli základ moderní teorie her položil John von Neumann na počátku minulého století (viz dále), první zmínku o teorii her, která má základ ve strategických rozhodnutích, můžeme nalézt již před dvěma a půl tisíci lety v Číně u filozofa a armádního generála Sun Tzu. V tomto článku bude teorie her aplikována na mezinárodní vztahy a budou zkoumány možnosti uplatnění různých skupin teorie her v obchodní politice a mezinárodní ekonomii na př́íkladu nejméně rozvinutých zemí (LDC).

\section{Definice teorie her a její členění dle různých kritérií}

Před tím, než bude popsán vývoj teorie her a aplikace této teorie na problematiku týkající se nejméně rozvojových zemí, je vhodné stručně vymezit základní teorie her a jejich různé typy.

Jak již bylo zmíněno v úvodu, neexistuje žádná všeobecně přijímaná definice toho, co je to teorie her. $V$ různých literaturách nalezneme různé pojmy, ale podstata je stejná všude - teorie her je vztah mezi dvěma nebo více účastníky (účastníci jsou nejen jednotlivci, ale také firmy, 
státy, různé zájmové skupiny lidí nebo integrační seskupení) a vyjednávání jejich nejlepší pozice. $\mathrm{V}$ následujícím přehledu jsou uvedeny alespoň některé ze známých definic, které naznačují principy teorie her:

- (relativně) důkladná analýza situace strategické závislosti (Dimand a Dimand, 1996)

- matematická analýza konfliktních situací (Dlouhý a Maňas, 2009)

- systematické studium vztahu mezi pravidly, volbou a výsledkem v konkurenčních situacích (Dobre, 2001)

- studie multipersonálních rozhodovacích problémů (Gibbons, 1992)

- studie strategické volby interakcí racionálních agentů - interaktivní teorie rozhodování (McCain, 2010)

- studie matematických modelů konfliktu a spolupráce mezi inteligentními racionálně rozhodujícími se účastníky (Myerson, 1997)

- soubor analytických nástrojů, které nám pomohou pochopit jevy, které pozorujeme, když se spojí účastníci rozhodování (Osborne a Rubinstein, 1994).

Chceme-li definovat teorii her, můžeme přijmout dva př́stupy: první analytický a druhý behaviorální (Dobre, 2001). Analytický př́stup spočívá v tom, že teorie her je analýza hry, kterou hrají neempiričtí ,ideální“ účastníci (hráči), kteří neodpovídají skutečným hráčům. Na druhé straně behaviorální přístup teorie her analyzuje skutečné účastníky a konfrontuje je s přesně stanovenými pravidly hry, jejich konflikty a strategiemi ${ }^{2}$. Strategii v teorii her definuje Davis (1997) jako kompletní plán akcí, popisující, co účastník bude dělat za všech možných okolností.

Základem analýzy teorie her je určit, která strategie je nejlepší odpovědí na strategii zvolenou ostatními účastníky. Nejlepší odpověd’ je definována McCainem (2010) jako strategie, která dává hráči maximální př́ínos, s ohledem na zvolenou strategii druhého hráče (nebo hráčů) nebo tu, u které lze očekávat, že si ji vybere.

Důležitými prvky teorie her jsou hráči, akce (strategie), odměna (výplata) a informace, které

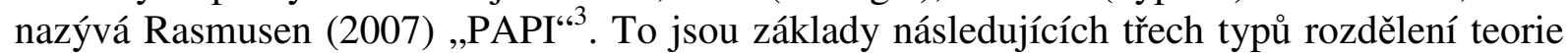
her: první je kombinace, kterou definuje Dobre (2001), Dlouhý a Maňas (2009), druhý je používán Gibbonsem (1992) a Fundenbergem a Tirolem (2000) a třetí typ je popisován Osbornem a Rubinsteinovou (1994):

- rozdělení teorie her na různé typy dle kritéria:

○ počtu hráčů - pokud se jedná o dva, je nazývána hrou o dvou hráčích, je-li účastníků více, jde o hru o n-hráčích, neboli hru koaliční

○ inteligence hráčů - v případě, že používají nejlepší strategie, jsou inteligentní, pokud využívají náhodnou strategii, jsou neinteligentní (častěji se používá termín př́rodní ${ }^{4}$ )

○ soubor strategií - tzv. Nashova rovnováha, který představuje vzájemné nejlepší reakce na ostatní strategie

\footnotetext{
${ }^{2}$ My se budeme zabývat právě tímto př́stupem.

${ }^{3}$ Tuto zkratku vytvořil ze slov players, actions, payoff a information.

${ }^{4}$ Marschack (1946) používal termín “fiktivní hráč”.
} 
○ suma výplat - pokud je konstantní (fixní), hovoříme o hře s nulovým součtem, pokud je proměnlivá, nazýváme ji hrou s nenulovým součtem

- rozdělení teorie her s ohledem na informace:

- statické a dynamické hry s kompletními informacemi (duopolní model Cournota a Bertranda a Stackelberga)

- statická a dynamická hra s neúplnými informacemi (aukce a firemní investování nebo měnové politiky ve smyslu regulace inflace a produktu)

- rozdělení teorie her na základě spolupráce a informace:

○ nekooperativní a kooperativní hry

○ strategické (normální forma) a extenzivní hry

○ hra s dokonalými či nedokonalými informacemi.

Specifické typy her zahrnují kombinaci všech výše uvedených kritérií, a proto jsou některé $\mathrm{z}$ nich zmíněny pro lepší přehlednost $\mathrm{v}$ tabulce 1 . Zde jsou uvedeny nejpoužívanější a nejznámější hry, kterým jsou přiřazeny určité hodnoty kritérií - to je počet hráčů, počet strategií na hráče, počet Nashovy rovnováhy, typ informací (ne/dokonalé) a suma výplat.

Tab. 1 Kritéria v teorii her

\begin{tabular}{lcccll}
\hline typ hry & počet hráčù & $\begin{array}{c}\text { počet strategií } \\
\text { na hráče }\end{array}$ & rovnováha & informace & $\begin{array}{c}\text { suma } \\
\text { výplat }\end{array}$ \\
\hline Bitva pohlaví & 2 & 2 & 2 & nedokonalé & nenulová \\
Krájení koláče & $n$ & nekonečný & proměnná & dokonalé & nulová \\
Cournotův model & 2 & nekonečný & 1 & nedokonalé & nenulová \\
Dolarová aukce & 2 & 2 & 0 & dokonalé & nenulová \\
Hra na sraba & 2 & 2 & 2 & nedokonalé & nenulová \\
Hod korunou & 2 & 2 & 0 & nedokonalé & nulová \\
Věžňovo dilema & 2 & 2 & 1 & nedokonalé & nenulová \\
Kámen, nůžky, papír & 2 & 3 & 0 & nedokonalé & nenulová \\
Hon na jelena & 2 & 2 & 2 & nedokonalé & nenulová \\
\hline
\end{tabular}

Pramen: vlastní zpracování

\section{Evoluce teorie her}

Ačkoli moderní matematický přístup $\mathrm{k}$ teorii her začíná s prací John von Neumanna „Zur Theorie der Gesellschaftspiele" ${ }^{\circ}$ (viz Luce a Raiffa, 1989), historie této matematickoekonomické disciplíny má hlubší kořeny. V této části článku budou zmíněni nejvýznamnější autoři a typy teorie her.

Peters (2008) uvádí vznik teorie her před dvěma a půl tisíci lety, kdy čínský generál a filozof Sun Tzu (544-496 př. n. 1.) napsal své dílo „Umění války“, jednu z nejstarších a nejúspěšnějších knih o vojenské strategii na světě. Tato práce byla založena na jeho životních zkušenostech a Sun popsal ve 13 kapitolách, jak je důležité umístování pozic ve vojenské strategii, která musí být založena na:

- $\quad$ objektivních podmínkách fyzického prostředí

\footnotetext{
${ }^{5}$ Poprvé byl publikován v roce 1928 v časopise Mathematische Annalen, 100, s. 295-320.
} 
- $\quad \mathrm{a}$ subjektivním přesvědčení ostatních konkurenčních subjektů $\mathrm{v}$ tomto prostředí.

Další historicky významnou prací, která se zabývá teorií her, je Talmud ${ }^{6}$. Jako první vysvětlili Aumann a Maschler jeden problém z teorie her v Babylonském Talmudu, a to koaliční problém bankrotu. (Orbay a Orbay, 2003) Aumann a Maschler (1985) popsali tři prŕíklady: první pojednává o třech věřitelích s pohledávkami 100, 200 a 300 a s možností získat majetek o velikosti 100, 200 a 300 (viz tabulka 2). Doporučení Talmudu je následující: nejmenší majetek (100) odpovídá nejmenšímu dluhu, zatímco rozdělení pozůstalosti 200 a 300 znamená nerovnoměrné rozdělení - zatímco pro majetek ve výši 200 je rozdělení nerovnoměrné $(50,75,75)$, pro majetek 300 je proporcionální $(50,100,150)$.

Tab. 2 Rozdělení dluhu

\begin{tabular}{ccccc}
\hline & & \multicolumn{3}{c}{ Dluh } \\
& & 100 & 200 & 300 \\
\hline \multirow{3}{*}{ nemovitost } & 100 & $33^{1} / 3$ & $33 \frac{1}{3} 3$ & $33 \frac{1}{3}$ \\
& 200 & 50 & 75 & 75 \\
& 300 & 50 & 100 & 150 \\
\hline
\end{tabular}

Pramen: vlastní zpracování dle Auman a Maschler (1985)

Druhý př́klad popisuje situaci dvou majitelů jednoho oděvu: zatímco jeden požaduje celý oděv, druhý požaduje ,,pouze“ půl - výsledkem je to, že první dostane $3 / 4$ a druhý $1 / 4$, protože zbývající polovina druhého majitele je rovnoměrně rozdělena mezi tyto dva majitele. Třetí př́iklad se vztahuje k Jeruzalémskému Talmudu a popisuje vznik koalice - koaliční hry - mezi druhým a třetím věřitelem proti věriteli prvnímu z prvního prríkladu. Věřitelé utvoří koalici, pokud je majetek menší nebo roven polovině celkového dluhu. Aumann a Maschler ukázali, že řešení založené na principu dělby oděvu je unikátním řešením pro veškerou problematiku bankrotu a shoduje se s podstatou těchto koaličních her. (Orbay a Orbay, 2003)

V polovině 17. století (přesně v roce 1654) byl popsán základ smíšené strategie, která vychází z konceptu pravděpodobnosti jako jednoho z pilír̆u teorie her Pierre de Fermata a Blaise Pascala (Hykšová, 2004). Na počátku 18. století, konkrétně roku 1713 se objevily první známé „minimax“ diskuse o dvou hráčích v teorii her v dopisech od Jamese Waldegraveho pro Pierre-de Remond Montmorta. Waldgrave popsal „minimax“ smíšené strategie, a to řešení (rovnováhy) karetní hry le $\mathrm{Her}^{7}$ (více Hykšová, 2004). Tato oblast teorie her byla také dále analyzována Montmortem a Nicholasem Bernoullim. Ve stejném roce začali diskutovat problém (a od roku 1728 s účastí Gabriela Cramera), který je v teorii her známý jak Petersburgský paradox. Takto byl jmenován v roce 1731 (zveřejněno 1738) Danielem Bernoulli, bratrancem Nicholase Bernoulliho. Stejně jako ve vysvětlení Waldgravovy karetní hry, v paradoxu se účatní hry dva hráči. Hráč A hodí minci a činí tak pořád, dokud nepadne „orel“. Souhlasí s tím, že dá hráči B jeden dukát, pokud padne „orel“" v prvním hodu, dva dukáty, pokud ve druhém, čtyři pokud ve třetím hodu, osm, čili s každým dalším hodem roste počet dukátů, kdy vždy musí zaplatit dvojnásobek. Cílem této hry je určit hodnotu očekávání hráče B. Paradox spočívá v tom, že ,nikdo není ochoten koupit (právo hrát tuto hru) za vysokou cenu, i když ta má očekávanou nekonečnou hodnotu“ (Ciecka, 2010). Nelze také opomenout přínos významného ekonoma Davida Huma (v roce 1739) a filozofa Jean Jacques

\footnotetext{
${ }^{6}$ Talmud je dva tisíce let starý židovský dokument, který je základem pro civilní, soudní a náboženské právo a má dva prameny původu - Babylon a Jeruzalém.

${ }^{7}$ Le Her je hazardní hra z 18. století, která se hraje standardně s 52 kartami a se dvěma hráči.
} 
Rousseau (v roce 1755) k teorii her, díky již zmíněné hře „hon na jelena“ (viz Skyrms, online).

Více než sto let po Waldgravově korespondenci popisuje Antoine Augustin Cournot matematický princip nedokonalé konkurence, a to zejména model duopolu, jehož řešení (strategie účastníků duopolu a výplata v podobě zisku) byla vysvětlena později jako Nashova rovnováha (čisté strategie). Na konci 19. století byla teorie her poprvé použita pro jiné než ekonomické řešení. V roce 1871 Charles Darwin popsal rovnovážný poměr pohlaví v evoluční biologii pomocí argumentu teorie her (Walker, online). Podobně jako Cournot, také Francis Ysidro Edgeworth uplatnit teorii her v mikroekonomickém modelu a v roce $1881 \mathrm{ji}$ aplikoval na problém stanovení výsledku obchodu mezi jednotlivými ekonomickými subjekty $^{8}$. Jak píše Walker (online), Edgeworth ukázal na př́kladu dvou komodit a dvou typech spotřebitelů, že smluvní křivka zmenší soubor konkurenční rovnováhy při nekonečném počtu spotřebitelů.

Další významný přínos $\mathrm{k}$ rozvoji teorie her přinesl Ernst Zermelo v roce 1913 na příkladu šachů, později známý jako Zermeli̊v teorém. Tento teorém na základě ověření Königa a Kalmara vysvětluje pojem výherní pozice: je-li hráč ve vítězné pozici, pak se může vždy získat vítězství bez ohledu na to, jakou strategii jiný hráč použije. (Schwalbe a Walker, $2001)^{9}$. Na jejich výsledky pak navázal již zmíněný von Neumann, jehož přínosy budou analyzovány $\mathrm{v}$ dalším odstavci. $\mathrm{V}$ roce 1921 Emile Borel poprvé publikoval články o problematice symetrické hry se dvěma hráči a nulovým součtem. Clánky byly celkem tři další následovaly v roce 1924 a 1927 (více Dimand a Dimand, 1992). Borel byl prvním, kdo se pokusil o matematizaci herní strategie, představil metodickou koncepci ve smyslu současné čisté strategie a hledal řešení ve smíšených strategiích ve smyslu současného řešení minimaxu. (Hykšová, 2004)

Rok 1928 je důležitým mezníkem v teorii her, nebot' díky práci John von Neumanna, se datuje existence teorie her jako jedinečné oblasti vědy. Von Neumann spolu s Zermelem, Königem a Kalmarem matematicky ověřil jejich řešení a stanovil rovnováhu ve hře o dvou hráčích s nulovým součtem ve smíšené strategie, známé jako Von Neumannưv teorém. Výsledek tohoto teorému je založen na maticové metodě a říká, že vždy existují smíšené strategie. Když hráči zvolí strategie $a, b$ s výsledky $c, d$ a očekávaná výplata prvního hráče je $p_{1}(a, b)$, tak pro stávající smíšené strategie $\left(\mathrm{a}^{*}, \mathrm{~b}^{*}\right)$ platí vztah:

$$
p_{1}\left(a^{*}, b^{*}\right)=\max _{a} \min _{b} p_{1}\left(c_{i}, d_{j}\right) \leq \min _{b} \max _{a} p_{1}\left(c_{i}, d_{j}\right)
$$

O šestnáct let později von Neumann publikoval s Oscarem Morgensternem knihu "Teorie her a ekonomického chování" (Neuman a Morgenstern, 1953). V této knize podali obecný popis strategických her, her s nulovým součtem pro dva a více hráčů, s nenulovým součtem, nekooperativní a kooperativní (koaliční) hry a také koncept teorie užitečnosti. Také zde podrobně formulovali ekonomické problémy teorie her a její aplikace na širokou škálu dalších vědeckých disciplín. Rok 1953 je tak považován za počátek teorie her jako matematické disciplíny.

\footnotetext{
${ }^{8}$ V Mathematical Psychics: An Essay on the Application of Mathematics to the Moral Sciences. C. Kegan Paul \& Co., London, 1881.

${ }^{9}$ Existuje mnoho interpretací tohoto teorému, viz Schwalbe aWalker (2001).
} 
Další významnou osobností v oblasti teorie her je John Forbes Nash ${ }^{10}$, který se na počátku 50. let minulého století začal touto problematikou zabývat, a to zejména nekooperativními hrami. Výsledkem byla výše uvedená Nashova rovnováha, která je koncepcí řešení smíšené hry pro dva a více hráčů, ve které se předpokládá, že každý hráč zná rovnovážné strategie ostatních, a žádný hráč nemůže získat užitek tím, že změní jednostranně pouze svou vlastní strategii. Koncept Nashovy rovnováhy se používá k analýze výsledku strategických interakcí různých účastníků v širokém spektru aplikací - od analýzy antagonistických situací (války a závody ve zbrojení), přes zmírňující konflikty v opakovaných interakcích, analýzy spolupráce nebo rizikového jednání lidí s odlišnými preferencemi k dosažení kooperativních výsledků družstva, až po aplikace na plynulost silničního provozu a organizování aukcí.

\section{Teorie her a její aplikace na řešení vybraných problémů v zemích LDC}

$\mathrm{Z}$ textu je zrrejmé, že teorie her a její různé aplikace našla své místo v různých vědních oborech a součástí denních (nejen) lidských aktivit. Využití teorie her roste také v oblasti mezinárodní ekonomie, spolupráce a mezinárodních vztahů (viz Correa, 2001, Snidal, 1985 nebo Bennett, 1995). V globalizovaném světě je více než 200 ekonomik, z toho dvě třetiny rozvojových zemí, proto je zřejmé, že tato skutečnost ovlivní mezinárodní vztahy, v našem případě vztahy založené na principu fungování teorie her. Tato část článku je věnována podrobné aplikaci teorie her ve vztahu k nejméně rozvinutým zemím.

\subsection{Definice nejméně rozvinutých ekonomik}

Nejméně rozvojové země jsou velmi specifickou skupinou ekonomik s vysokým stupněm zaostalosti. Téměř všechny tyto ekonomiky jsou geograficky umístěny v ,pásu chudoby“11, s populací více než 880 milionů, což činí asi 13 procent světové populace (Kaba, 2011), produkují méně než 0,87 procent světového HDP a jejich podíl na světovém obchodě je 1,1 procent (WTO, 2011).

Poprvé byl použit termín nejméně rozvinutých zemí v roce 1971. Zemím, kterých bylo původně 25 , nyní 48 (viz tabulka 3), je věnována ze strany mezinárodních institucí a vyspělejších států zvýšená pozornost s cílem odstranit jejich zaostalost. Ekonomiky, které chtějí být zařazeny do skupiny nejméně rozvinutých zemí, musí splňovat určitá kritéria OSN (nízká úroveň národního důchodu, vysoký stupeň hospodářské zranitelnosti a nízký stupeň lidského potenciálu, více Majerová, 2011) a jsou charakterizovány těmito vlastnostmi (UNCTAD, 2010):

- nízká úroveň HDP na obyvatele (a paradoxně vysoké tempo růstu HDP)

- nízká produktivita zemědělské výroby

- vysoká zadluženost

- nedostatečná diverzifikace

- vysoký počet lidí žijících pod hranicí chudoby

- velký počet lidí nakažených infekčními nemocemi jako je HIV/AIDS, malárie, tuberkulóza a průjmová onemocnění (a umírající na jejich následky)

\footnotetext{
${ }^{10}$ V roce 1994 byl Nash (s Johnem Harsanyim a Reinhardem Seltenem) oceněn Nobelovou cenou za přínos v oblasti nekooperativních her. V roce 2005 Robert J. Aumann and Thomas C. Schellig byli ocenění Nobelovou cenou za úspěchy na poli kooperativních her.

${ }^{11}$ Jedná se o území mezi obratníkem Raka a Kozoroha, výjimkou je Afghánistán.
} 
- vyšší stupeň závislosti na vývozu komodit a potravin a dovozu paliv.

Tab. 3 Přehled zemí LDC dle regionů (k 1. lednu 2012)

\begin{tabular}{lllll}
\hline Afrika & & Asie & Oceánie & Karibik \\
\hline Angola & Madagaskar & Afghánistán & Kiribati & Haiti \\
Benin & Mali & Bangladéš & Samoa & \\
Burkina Faso & Mauretánie & Bhútán & Šalamounovy & \\
Burundi & Mosambik & Kambodža & ostrovy & \\
Čad & Niger & Laos & Tuvalu & \\
DR Kongo & Rwanda & Myanmar & Vanuatu & \\
Džibuti & Sv. Tomáš a Princův ostrov & Nepal & & \\
Rovníková Guinea & Senegal & Východní & & \\
Eritrea & Sierra Leone & Timor & & \\
Etiopie & Somálsko & Jemen & & \\
Gambie & Súdán & & & \\
Guinea & Tanzanie & & & \\
Guinea-Bissau & Togo & & & \\
Komory & Uganda & & & \\
Lesotho & Zambie & & \\
Libérie & & & \\
\hline
\end{tabular}

Pramen: vlastní zpracování

Výše uvedené charakteristiky mohou být základem pro analýzu teorie her na př́kladu těchto zemí, at' už z hlediska mezinárodního obchodu, obchodní politiky, poskytování státních dotací, nebo prodeje drog či infekčních onemocnění.

\subsection{Aplikace teorie her na vybrané problémy nejméně rozvinutých ekonomik}

V této části článku budou analyzovány tři situace, které mohou nastat v nejméně rozvinutých zemích z ekonomického hlediska, a mohou být řešeny pomocí teorie her:

- aplikace teorie her na základní rozpor mezinárodní ekonomie - tedy liberalizaci a protekcionismus

- aplikace teorie her $\mathrm{v}$ mikroekonomii - zejména na obchodní politiku a zapojení nejméně rozvinutých zemí do vyspělých trhů

- aplikace teorie her na zdravotní problematiku - konkrétně možnost poskytování levnějších léků na léčení malárie pro nejméně rozvinuté země.

\section{Liberalizace versus protekcionismus}

Princip protekcionismu je starý jako lidstvo samo, stejně jako snahy o jeho odstranění liberalizací mezinárodního obchodu. Globální liberalizace trhu je všeobecně považována za způsob rozvoje nejméně rozvinutých zemí, ale není to zcela tak jednoznačné. Ani z pohledu teorie her není efekt liberalizace tak zřejmý, nebot' zavedení ochranářských opatření (typicky dominantní strategie) vede k Nashově rovnováze, i když je neefektivní.

Nyní si představme, že nejméně rozvinutá země (nazvěme ji Ledoc) vstoupí do mezinárodního obchodu s vyspělým světem (dále jen Vyspa) a oba účastníci si mohou vybrat strategii liberalizace $(\mathrm{L})$, nebo protekcionismu $(\mathrm{P})$. Vytvoří tak následující matici výplat (obrázek 2), kdy číselné hodnoty představují fiktivní př́ijmy (např. v milionech) ze vzájemného obchodu. Z matice vidíme, že pokud oba účastníci vyberou liberalizaci, získají 
tím výnosy z obchodu $(8,8)$, pokud využívají protekcionistická opatření, např. cla, oba ztrácejí $(5,5)$, i když dosáhli (neefektivní) rovnováhy. V situaci, kdy Vyspa liberalizuje obchod, pro nejméně rozvinuté země je lepší přijmout strategii protekcionismu $(9,4)$, a i když Vyspa využije také protekcionismu, pro nejméně rozvinuté země je stále výhodnější chránit své trhy (výnos 5 je stále vyšší než výnos 4). Toto je př́íklad hry s dominantní strategickou rovnováhou.

Obr. 2 Matice výplat

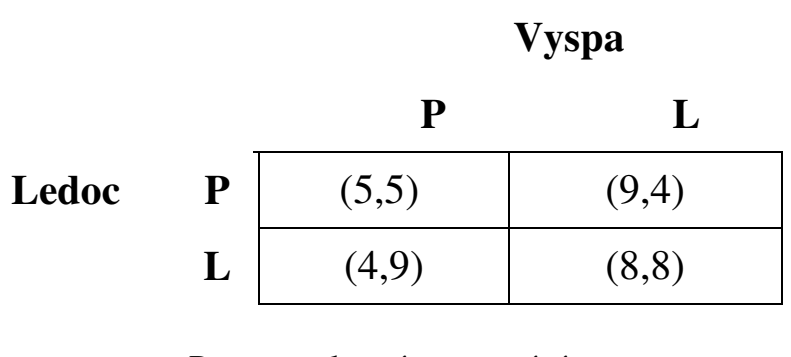

Pramen: vlastní zpracování

\section{Monopol a nováček}

Dalším př́kladem aplikace teorie her na nejméně rozvinuté země má mikroekonomický základ - předpokládejme existenci monopolu v rozvinuté ekonomice Mone a potenciální zájemce o vstup „nováčka“ na trh (pro zachování kontinuity jej nazvěme stejně - Ledoc). Při rozhodování Ledocu o vstupu na trh je jedním z problémů to, že nezná mezní náklady Mone mohou být vyšší nebo nižší než jeho náklady. Jsou-li vyšší, nebude Mone „bojovat“ s firmou z nejméně rozvinuté země o postavení na trhu kvůli své neschopnosti snížit ceny. Ale pokud jsou mezní náklady Mone nižší, bude s nejméně rozvinutou zemí „bojovat“ o postavení na trhu a vyhraje. Tento stav lze ilustrovat pomocí herního stromu, kde jsou uvedeny výplaty hráčů v závorkách, jejichž hodnoty odpovídají výše uvedeným závěrům. Vlevo ukazuje herní strom (obrázek 3) pasivitu Mone s vyššími mezními náklady, pravý herní strom (obrázek 4) odráží aktivní „boj“ monopolní ekonomiky, kde právě vstoupil konkurent z nejméně rozvinuté země.

\section{Obr. 3 Vyšší mezní náklady Mone}

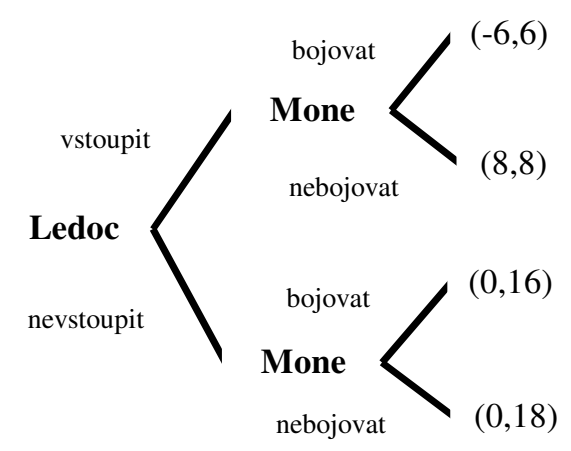

Obr. 4 Nižší mezní náklady Mone

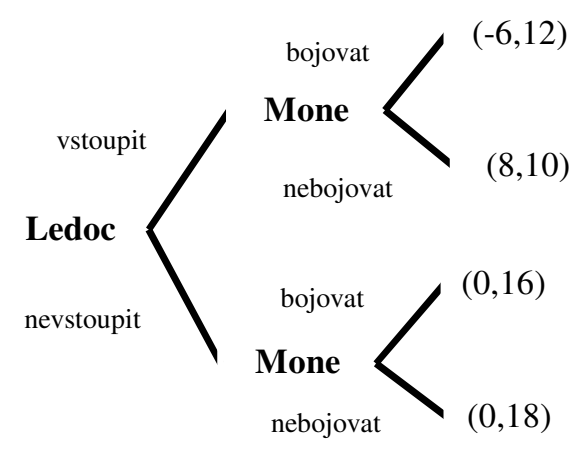

Pramen: vlastní zpracování

Výše uvedené případy jsou ,pouze” modely, v reálném světě je obvyklejší (i když velmi nákladné), že monopoly ( $v$ našem př́ípadě Mone), v případě, že nováčci (Ledoc) vstoupí na trh, bojují s firmami z nejméně rozvinutých zemí, protože ví, že jako tradiční výrobce vytlačí méně rozvinuté země z trhu a obnoví svůj monopol. Výsledkem je tedy vždy ztráta pro firmy 
z nejméně rozvinutých zemí. Negativní úlohu zde může sehrát i stát prostř̌ednictvím dotací pro Mone. Na druhou stranu mohou získat podporu i firmy z nejméně rozvinutých zemí, a v tomto př́ípadě tyto firmy vždy vstoupí na trh ovládaný Mone. Toto je případ teorie her $\mathrm{s}$ nedokonalými informacemi.

\section{Léky proti malárii zemím LDC}

Šîrení infekčních nemocí, jako je malárie, AIDS a tuberkulóza jsou velmi závažné problémy nejméně rozvinutých zemí, zejména z důvodu nedostupnosti vhodných léků. Problémem není jejich nedostatek, ale cena - mnoho takto zdravotně postižených lidí v rozvojových zemích $\mathrm{s}$ př́ijmem nižším než 1 dolar na den si nemohou dovolit platit za ošetření tisíce dolarů. Řešením je snížit cenu léků pro tyto pacienty, ale to je doprovázeno určitými podmínkami farmaceutických firem. Jednou z těchto podmínek, pro zachování zisku firem může být prodej generických léků ${ }^{12}$, s podmínkou zákazu (většinou spekulativního) zpětného prodeje do vyspělejších (a bohatších) ekonomik. Toto je případ hry s jedním pokusem.

Předpokládejme tedy, že v nejméně rozvinuté zemi (Ledoc) začne farmaceutická společnost (Farm) distribuovat léky na léčbu malárie, které může prodávat za dvojí cenu - vysokou (V) a nízkou (Z). Ledoc může uplatnit pouze dvě strategie - přijmout omezení dalšího prodeje (ano, A), nebo nepřijmout (ne, N). Přínosy jsou popsány čtyřmi čísly - číslo 0 je situace beze změny, -10 znamená zhoršení současné situace, 10 znamená lepší situaci a 20 (lepší než 10) situaci nejlepší. K dispozici jsou tři varianty - za prvé, když Farm nepočká až Ledoc přijme omezení a nabízí léky, další, když oba účastníci „hrají“ ve stejnou dobu (Farm nabízí léky a Ledoc přijme podmínku) a třetí, když Farm přichází do hry (tedy na trh) až poté, co Ledoc přijal potřebná opatření.

Výsledky prvních dvou zmíněných případů jsou stejné - pokud Farm zavede vysoké ceny léků, pro oba hráče je lhostejné, zda Ledoc zavede požadovaná opatření - návratnost je vždy 0,0 (tzv. status qou). Jiné je to v prrípadě prodeje léků za nízké ceny, kdy výplata firmy Farm je 10, v případě přijetí opatření Ledocem. Pokud však Ledoc opatření nepřijme, výplata se sníží na -10. Na druhou stranu ovšem přínos Ledocu je 10, pokud zavede opatření, pokud ne, odměna je 20 (protože má zisky z prodeje léků do jiných zemí). Tyto strategie a matici výplat zobrazuje herní strom na obrázku 5.

\section{Obr. 5 Výplaty v případě zahájení hry firmou Farm, resp. oběma hráči}

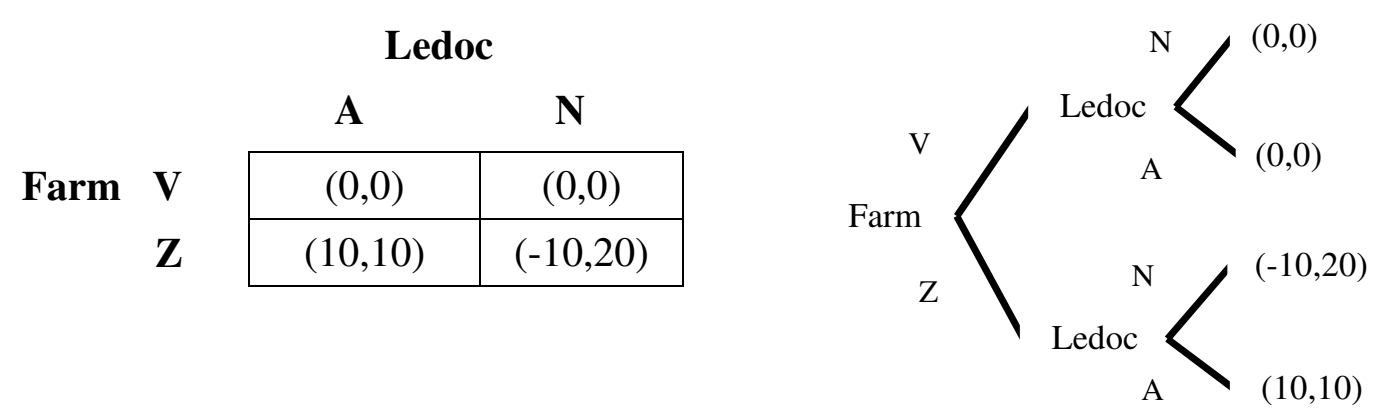

Pramen: vlastní zpracování

\footnotetext{
${ }^{12}$ Generické léky jsou ekvivalenty originálních léků, které mohou být prodávány poté, co skončí jejich patentová ochrana a jsou více než o 80 procent levnější než jejich originální varianta.
} 
Pokud Farm bude čekat na opatření Ledocu, struktura herního stromu se změní (zatímco maticová struktura zůstává beze změny). Nepřijetí znamená status quo pro oba hráče $\mathrm{v}$ př́ípadě vysokých cen, při nízkých cenách je výplata $(20,-10)$ pro nejméně rozvinutou zemi (Ledoc) i pro Farm. V př́ípadě přijetí omezujících opatření za účelem dalšího prodeje pak znamená status quo při vysokých cenách a $\mathrm{v}$ případě nízkých cen znamená opět zlepšení $(10,10)$. Tyto situace jsou uvedeny v matici a v herním stromu na obrázku 6.

\section{Obr. 6 Výplaty v případě zahájení hry Ledocem}

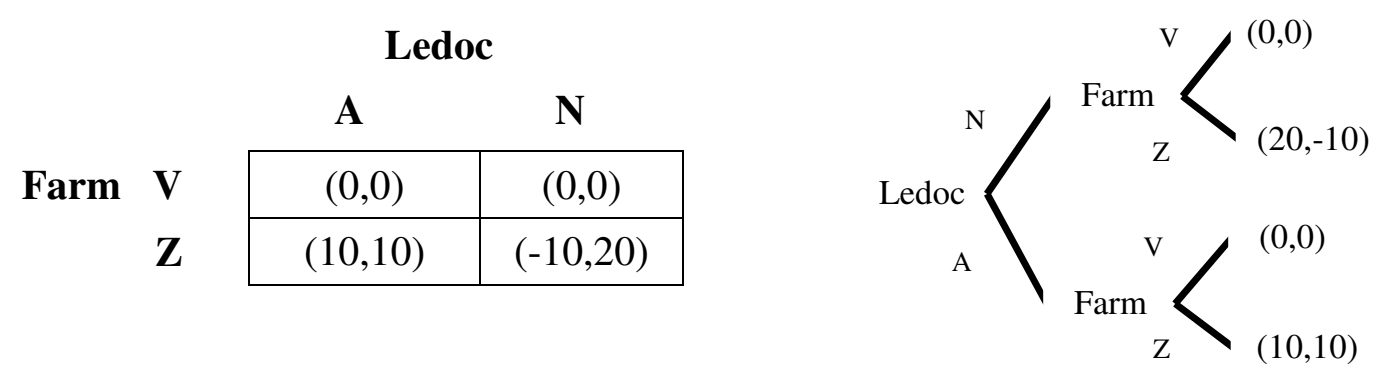

Pramen: vlastní zpracování

Tento typ hry je příkladem toho, jak důležité je být první nebo další hráč a jak důležitá je spolupráce mezi různými aktéry, i když to může být někdy vynucené a hráči musí hrát podle pro ně ne vždy výhodného pravidla.

\section{Závěr}

Teorie her doprovází lidstvo od jeho začátků, a to nejen $\mathrm{z}$ historického hlediska prostřednictvím válečných strategií (Sun Tzu), právního řešení (Talmud) či ekonomických problémů (duopol), ale také „od kolébky do hrobu“, prostřednictvím dětských her (kámen, nůžky, papír), studentské zábavy (hra „na sraba“), nebo behaviorálních her dospělých (bitva pohlaví nebo lov na jelena).

I když jednotná definice teorie her neexistuje, její základ je jasný - je to matematická disciplína, která se zabývá otázkou optimálního chování účastníků a určením výsledné rovnováhy. $\mathrm{V}$ tomto článku byl zvolen behaviorální přístup k teorii her, založený na zkoumání strategií jednotlivých hráčů a řešení jejich vzájemných konfliktů. Pro tento článek byla vybrána jedna oblast aktivit teorie her, a to oblast ekonomická. Ta byla dále zúžena na problematiku mezinárodního obchodu, zejména ve vztahu $\mathrm{k}$ nejméně rozvinutým zemím LDC. Tyto země jsou obecně považovány za „nejslabší hráče“ v oblasti mezinárodního obchodu, neschopné těžit $\mathrm{z}$ výhod mezinárodního obchodu $\mathrm{z}$ důvodu svých nedostatečných znalostí.

V tomto článku jsou uvedeny tři příklady z ekonomické aplikace teorie her na nejméně rozvinuté země. Prvním je hra o volbu mezi volným obchodem a ochranářskou politikou, druhým možný průnik na trhy ovládané monopolní firmou a třetím prodej generických léků proti malárii v nejméně rozvinutých zemích. Pokud jde o první př́klad, bylo zjištěno, že pokud oba účastníci zvolí liberalizaci, oba budou mít zisky z obchodu, pokud použijí protekcionismus, oběma přinese ztrátu, i když dosáhnou (neefektivní) rovnováhy. V situaci, kdy druhý účastník zvolí liberalizaci nebo protekcionismus, je pro nejméně rozvinuté země lepší použít protekcionismus. Výsledkem hry „Monopoly a nováček“ je „boj“ monopolu s firmou z nejméně rozvinutých zemí (což je spojeno se značnými finančními náklady). 
Nováček vždy ztrácí, ale to může být změněno podporou státu. „Farmaceutická“ hra má několik řešení v závislosti na pořadí, ve kterém každý účastník vstoupí na trh: když vstoupí do hry jako první farmaceutická společnost, je schopna sledovat pravidla (tedy dodržování jí stanoveného opatření o zákazu zpětného odprodeje léků). Ocenění léků však může být jiné, než když do hry vstoupí jako druhý hráč. V každém případě je dosaženo optima, když jsou léky dodávány nejméně rozvinutým zemím za nižší ceny $\mathrm{v}$ souladu s podmínkami stanovenými farmaceutickou firmou.

\section{Literatura:}

[1] AUMAN, R., MASCHLER, M. Game theoretic analysis of a bankruptcy problem from the Talmud. Journal of Economic Theory. 1985, vol. 36, no. 2, s. 195-213. ISSN 00220531.

[2] BENNETT, P. G. Modeling Decisions in International Relations: Game Theory and Beyond. Mershon International Studies Review. 1995, vol. 39, no. 1, s. 19-52. ISSN 10791760.

[3] CIECKA, J. Daniel Bernoulli on the Measurement of Risk. Journal of Legal Economics [online]. 2010 [cit. 11.12.2011]. Dostupné z: http://www.allbusiness.com/sciencetechnology/mathematics/14622371-1.html.

[4] CORREA, H. Game Theory as an Instrument of the Analysis of International Relations. Ritsumeikan Annual Review of International Studies. 2001, vol. 14, s. 1-22. ISSN 13478214.

[5] DAVIS, M. D. Game Theory: a nontechnical Introduction. Mineola: Dover Publications, 1997. ISBN 0-486-29672-2.

[6] DIMAND, M. A., DIMAND, R. W. A History of Game Theory, Volume I.: From Beginnings to 1945. In Routledge Studies in History of Economics. London and New York: Routledge, 1996. ISBN 0-415-07057-3.

[7] DIMAND, R. W., DIMAND, M. A. The Early History of the Theory of Strategic Games from Waldegrave to Borel. In Toward History of Game Theory. Annual Supplement of History of Political Economy. Durham and London: Duke University Press, 1992. ISSN 0018-2702.

[8] DLOUHÝ, M., MAŇAS. M. Games and Economic Decisions. Praha: Oeconomica, 2009. ISBN 80-245-0628-9.

[9] DOBRE, C. I. Implication of Game Theory to International Trade. Revista Tinerilor Economisti, 2001, vol. 1, s. 132-137. ISSN 1583-9982.

[10] FUNDENBERG, D., TIROL. J. Game Theory. Cambridge: MIT Press, 2000. ISBN 0-262-06141.

[11] GIBBONS, R. Game Theory for Applied Economists. Princeston: Princeston University Press, 1992. ISBN 0-691-00395-5.

[12] HYKŠOVÁ, M. Several Milestones in the History of Game Theory. In Jubiläen Change oder Plage? VII. Österreichisches Symposion zur Geschichte der Mathematik, Wien, 2004, s. 49-56. [online]. 2004 [cit. 11.1.2012]. Dostupné z: http://euler.fd.cvut.cz/ hyksova/publ_e.html.

[13] KABA, M. The UN wants to get half of the countries out of poverty by 2020. The 4th UN Conference on the Least Developed Countries, 9-13 May 2011. [online]. 2011 [cit. 11.2.2012]. Dostupné z:

http://www.un.org/wcm/content/site/ldc/home/template/news_item.jsp?cid=27742.

[14] LUCE, R. D, RAIFFA, H. Games and Decisions. Introduction and Critical Survey. Mineola: Dover Publications, 1989. ISBN 0-486-65943-7. 
[15] MAJEROVÁ, I. Ekonomické a politické aspekty vývoje zemí LDC a jejich perspektivy v rámci světové ekonomiky. Karviná: SU OPF, 2011, 160 s. ISBN 978-80-7248-703-5.

[16] MAŇAS, M. Games and Economic Decisions. Praha: Oeconomica, 2003. ISBN 80245-0628-9.

[17] MARSCHACK, J. Neumann's and Morgenstern's new Approach to static Economics. The Journal for Political Economy, 1946, vol. LIV, s. 97-115.

[18] McCAIN, R. A. Game Theory. A Nontechnical Introduction to the Analysis of Strategy. Drexel University, Philadephia, 2010. ISBN 0-324-17572-8.

[19] MYERSON, R. B. Game Theory: Analysis of Conflict. Harvard University Press, Harvard, 1997. ISBN 978-0674341166.

[20] NEUMANN, J. von, MORGENSTERN, O. Theory of Games and Economic Behavior. Princeston: Princeston University Press, 1953.

[21] ORBAY, B. Z., ORBAY, H. Talmudic Division as a Cartel Rule. Journal of Economics and Business, 2003, vol. 55, no. 2, s.167-175. ISSN 0148-6195.

[22] OSBORNE, M. J., RUBINSTEIN, A. A Course in Game Theory. Cambridge: MIT Press, 1994. ISBN 0-262-65040-1.

[23] PETERS, H. Game Theory: A multilevel Approach. Heidelberg: Springer Verlag, 2008. ISBN 978-3540692904.

[24] RASMUSEN, E. Games and Information: an Introduction to Game Theory. Blackwell Publishing, Oxford, 2007. ISBN 978-1405136662.

[25] SCHWALBE, U. WALKER. P. Zermelo and the Early History of Game Theory. Games and Economic Behavior, 2001, vol. 34, no. 2, s. 123-137. ISSN 0899-8256.

[26] SKYRMS, B. The Stag Hunt. [online]. [cit. 1.2.2011]. Dostupné z: http://www.lps.uci.edu/home/fac-staff/faculty/skyrms/StagHunt.pdf.

[27] SNIDAL, D. The Game Theory of International Politics. World Politics, 1985, vol. 38, no. 1, 22-57. ISSN 0043-8871.

[28] UNCTAD. The Least Developed Countries Report 2010. Towards a New International Development Architecture for LDCs. New York and Geneva: United Nations, 2010.

[29] WALKER, P. An Outline of the History of Game Theory. [online]. [cit. 17.2.2012]. Dostupné z: http://william-king.www.drexel.edu/top/class/histf.html.

[30] WTO. International World Trade Statistic 2011.[online]. 2011. [cit. 17.3.2012]. Dostupné z:

http://www.wto.org/english/res_e/statis_e/its2011_e/its11_world_trade_dev_e.pdf.

JEL C70, C71, C72

Ing. Ingrid Majerová, Dr.

odborný asistent Katedry ekonomie

Obchodně podnikatelská fakulta v Karviné

Slezská univerzita v Opavě

Univerzitní náměstí 1934, 73340 Karviná

majerova@opf.slu.cz 